\title{
PENGATURAN MENGENAI PESAWAT UDARA MILITER MENURUT HUKUM UDARA INTERNASIONAL
}

\author{
Eva Johan \\ Fakultas Hukum \\ Universitas Sultan Ageng Tirtayasa
}

\begin{abstract}
Abstrak
Pada dasarnya, udara wilayah negara ditutup untuk pesawat negara lain. Tidak ada pesawat bisa terbang di atas wilayah lain atasnya negara atau tanah tanpa otorisasi sebelum negara. Ini berarti setiap penerbangan dilakukan adalah melanggar wilayah udara negara lain. Karakteristik wilayah udara nasional sebagai media gerakan membuatnya sensitif untuk keamanan dan pertahanan negara di bawah (kolong Negara). Kelebihan dari wilayah udara untuk serangan militer, yakni kecepatan, jangkauan, surprice dan penetrasi, dapat dioptimalkan melalui media udara menggunakan pesawat. Untuk itu, setiap negara rias keamanan wilayah udara standar ketat dan kaku.
\end{abstract}

Kata Kunci: wilayah udara, pesawat terbang, pelanggaran

\begin{abstract}
Basically, air territory of a state is closed for other state aircraft. No state aircraft able to fly over territory of another state or land thereon without authorization before. It means every flight done is violating air territory of another country. The characteristic of national air territory as a movement media makes it sensitive for security and defense of the state beneath (negara kolong). The advantages of air territory for military attack, namely speed, range, surprice and penetration, could be optimized through air media using aircraft. In order that, every state dressing its security air territory standard strictly and rigidly.
\end{abstract}

Keywords: air territory, aircraft, violation

\section{PENDAHULUAN}

Kecepatan dan sifat bebasnya pesawat udara dari rintangan permukaan bumi, menjadikan alat transportasi ini memiliki potensi penggunaan secara militer yang luar biasa. Selain itu, ruang udara sebagai media bergeraknya pesawat terbang telah menjelma menjadi jalan datangnya serangan militer yang sangat rawan.

Pada dasarnya wilayah udara suatu Negara tertutup bagi pesawat udara Negara lain. Oleh karenanya, setiap penerbangaan yang memasuki wilayah udara Negara oleh pesawat Negara lain tanpa izin sebelumnya dari Negara yang wilayahnya dimasuki, merupakan pelanggaran wilayah udara.

Sifat tertutup ruang udara nasional itu dapat dipahami mengingat udara sebagai media gerak amatlah rawan ditinjau dari segi pertahanan dan keamanan Negara kolong. Keuntungankeuntungan serangan militer seperti kecepatan (speed), jangkauan (range), pendadakan (surprice), penyusupan Eva Johan 
(penetration) dapat dilakukan dengan optimal hanya melalui media udara dengan pesawat udara. Hal ini mendorong setiap Negara mengenakan standar penjagaan ruang udara nasionalnya secara ketat dan kaku.

Dalam beberapa tahun terakhir, beberapa kasus-kasus pelanggaran wilayah udara Indonesia oleh pesawatpesawat militer asing telah sering terjadi.

Seringkali terjadi ketegangan antara Indonesia-Australia lantaran banyaknya penerbangan gelap (blackflight) dan penerbangan tanpa izin. Sempat pula terjadi ketegangan ketika pesawatpesawat F-5 Tiger TNI-AU 'mengusir' jet-jet F-18 Hornet milik Angkatan Udara Australia yang dinilai telah memasuki wilayah udara Indonesia di atas Pulau Roti tanpa izin. Sebelumnya, sebuah F-18 Hornet AS yang tidak diketahui berasal dari kapal induk mana 'terpaksa' melakukan technical landing setelah kepergok F-16 IAF di perairan Biak. Pernah juga terjadi, 5 pesawat F-18 Hornet AS juga nyaris menembak pesawat F-16 TNI AU yang bermaksud melakukan identifikasi atas penerbangan yang mereka lakukan di barat laut Pulau Bawean. Ketika 2 pesawat F-16 TNI AU berusaha mengontak pesawat F-18 tersebut, mereka justru mengunci (lock on) keduanya dan bersiap untuk menembak. Berdasarkan observasi TNI
AU, pesawat-pesawat ini merupakan bagian dari satu Armada Angkatan Laut AS yang terdiri dari 1 kapal induk, 2 kapal fregat dan 1 kapal tanker dan mengaku memiliki izin untuk melintas. (www.makaarim.wordpress.com). Kasus yang paling hangat adalah masuknya pesawat udara Malaysia di perairan ambalat(www.tvone.co.id) yang juga di klaim sebagai wilayah kedaulatan Malaysia sejak belum selesainya perundingan batas wilayah kedua Negara, antara Indonesia dan Malaysia.

Pasal 29 hingga Pasal 32 UNCLOS 1982 telah mengatur dan memberikan definisi mengenai Kapal Perang, dimana kapal perang tersebut memiliki kekebalan dan dapat melintas tanpa pemberitahuan Negara pantai sepanjang melalui alur yang telah disediakan pada laut territorial Negara pantai. Sudah dapat dipastikan setiap kapal perang selalu dikawal oleh pesawat udara militer yang terbang di atasnya, hal ini yang merupakan kendala terbesar saat ini karena belum ada ketentuan internasional yang mengatur hal tersebut. Terlebih lagi ada Negaranegara yang belum meratifikasi UNCLOS 1982, sehingga hal tersebut akan menyulitkan Negara yang dilewati oleh pesawat udara militer asing tersebut. Upaya TNI AU umumnya melakukan intersepsi (pencegatan) 
terhadap pesawat yang melanggar dan memberikan teguran atas pelanggaran tersebut. Sesuai aturan internasional, pesawat tempur yang melintasi udara sebuah Negara berdaulat harus melaporkan terlebih dahulu ke pengontrol lalu lintas udara setempat, tidak boleh melakukan provokasi, ancaman, terlebih melakukan manuver-manuver.

Tulisan ini tidak akan membahas hal rumit di atas, tetapi akan mencoba melihat sejauhmana pengaturan mengenai pesawat udara militer menurut hukum udara internasional dan pengaturan ketika pesawat udara militer tersebut memasuki wilayah udara Indonesia. Bagaimana pemahaman yang harus diberikan terhadap kasus pelanggaran kedaulatan wilayah udara tersebut, dengan melakukan pendekatan melalui hukum udara.

Mengingat betapa pentingnya Indonesia menjaga kedaulatan wilayahnya di udara maka perlu adanya suatu harmonisasi aturan nasional dan internasional di bidang hukum udara, terutama mengenai penerbangan militer bagi Negara asing. Dalam tulisan ini akan dibatasi permasalahan hanya mengenai: (1)bagaimana ketentuan mengenai pesawat udara militer asing yang masuk ke dalam kedaulatan udara suatu Negara menurut hukum udara internasional (2)bagaimana pengaturan- nya dalam hukum nasional.

\section{Teori Kedaulatan}

Kerangka pemikiran yang digunakan adalah landasan yuridis dan landasan teoritis. Landasan yuridis yaitu Convention on International Civil Aviation of 1944, Annex Konvensi Chicago 1944, Undang-undang No. 1 Tahun 2009 tentang Penerbangan, Undang-undang No. 43 Tahun 2008 tentang Wilayah Negara, Undangundang No. 3 Tahun 2002 tentang Pertahanan Negara dan Undang-undang no. 34 tahun 2004 tentang TNI. Sedangkan landasan teoritis yaitu teori kedaulatan.

Jean Bodin dalam tulisannya menyatakan pentingnya suatu kedaulatan bagi pelaksanaan pemerintahan dan sejak itu kedaulatan merupakan masalah sentral dalam pembahasan perangkat neagra modern dan teori dari hokum internasional. (J.L.Briefly, 1963;7). Hubungannya dengan kedaulatan Negara di udara mulai berkembang pada abad 20, dimana beberapa penulis telah berpendapat bahwa di udara adalah bebas (Wenceslas J. Wagner, 1970:13) yang kemudian berkembang beberapa teori yang berhubungan dengan kedaulatan negara di udara.

Teori kedaulatan Hans Kelsen dalam bukunya Theory of Law yang 
diterjemahkan Anders Wedberg, bahwa kedaulatan adalah satu kualitas penting dari Negara yang berarti bahwa Negara tersebut merupakan satu kekuasaan tertinggi dan kekuasaan didefinisikan sebagai hak atau kekuasaan untuk memaksa, lebih lengkap dijelaskan:

The most important consequence of the theory which proceed from the primacy of national law is that the State whose legal order is the starting point of the whole construction can be considered to be sovereign...The statement that sovereignty is essential quality of State means that the State is a supreme authority. Authority is usually defined as the right or power to issue obligating commands(Hans Kelsen, 1961:383).

Hukum internasional hanya berlaku karena diakui oleh Negara berdaulat, lebih jauh dijelaskan:

If the phenomena of law are interpreted according to the hypothesis of the primacy of national law, one national level order only, and therefore one State only, can be conceived as sovereign. This hypothesis is possible only from the point of view of one national legal order...The necessary relationship between this state and other states can be established only by international law, and only if it is admitted that international law determines the spheres of validity of the legal orders of states(Hans Kelsen, 1961:385).

Kedaulatan Negara di ruang udara dan ruang angkasa oleh Lyclama Nijeholt pada tahun 1910, yang dikutip oleh Priyatna Abdurrasyid, yang menyatakan bahwa:

Whilst the technical expert from one century to another was engaged in investigating the problem of navigation of the air, the jurist could afford to look on calm and unmoved as one experiment after another failed...So longas there were available only undirigible balloons, dangerous and expensive, absolutely unfit for regular traffic, aerial navigation was therefore necessarily confined to some very infrequent ascents, such as attractions at exhabitions, for military purposes; it not created situations and relationship demanding the immediate attention of the legislator...recent years have proved such a splendid success for aeronautics that it seems justifiable for law to begin to take its share in the aerial labor.(Priyatna Abdurrasyid,1972:64)

Beberapa teori yang lahir setelah Konvensi Chicago 1944 untuk memberikan pengertian atas batas ruang udara, dapat dikemukakan sebagai berikut: (1)Teori tentang penafsiran luas ruang udara secara logika-yuridis, bahwa ruang udara "air space” menurut pengertian Konvensi Chicago 1944 adalah jalur ruang udara di atmosfir yang berisikan cukup udara dimana pesawat udara dapat bergerak karena reaksi udara kepadanya sehingga mendapat gaya angkat (lift), jarak ketinggian kedaulatan Negara di atmosfir kemudian akan ditentukan oleh kesanggupan pesawat udara mencapai ketinggian tertentu (ceiling). (Priyatna Abdurrasyid, 1972; 102). (2)Teori Penguasaan Cooper 
(Cooper's Control Theory). Cooper memberikan pengertian kedaulatan Negara di ruang udara yaitu ditentukan oleh kemampuan Negara-negara yang bersangkutan untuk menguasai udara yang ada di atas wilayahnya. (Priyatna Abdurrasyid,1972;103) Dari segi hukum dijelaskan bahwa ruang udara ialah bagian atmosfir bumi yang tertentu dimana terdapat cukup gas udara (gaseous air) untuk memungkinkan penerbangan dengan pesawat udara. (Priyatna Abdurrasyid,1972;104). (3)Teori Kerukunan merupakan teori yang lahir atas perbedaan kepentingan mengenai permasalahan ruang udara di atas jalur laut territorial dan jalur keamanan perlindungan Negara. Teori kerukunan ini berunsurkan pokokpokok: (a)Menghindarkan sedapatdapatnya timbul atau dikemukakannya keberatan-keberatan oleh pihak ketiga; (b)Kepekaan terhadap kepentingan yang sah/legitimate dari Negara-negara lain; (c)Akomodasi untuk menyesuaikan kedua kepentingan tersebutterdahulu untuk sampai kepada pengakuan baik secara terang-terangan atau diam-diam. Kesediaan untuk menemukan akomodasi kepentingan harus dilakukan tanpa mengorbankan kepentingan nasional yang vital.(Priyatna Abdurrasyid, 1972;139).

Konvensi Chicago 1944 tidak mengatur mengenai apa yang dimaksud dengan pesawat udara (aircraft). Pesawat udara adalah setiap pesawat yang memiliki kemampuan bergerak di ruang udara di atmosfir, karena adanya reaksi udara kepada pesawat tadi dan reaksi ini bukan karena reaksi permukaan bumi (misalnya kapal hydrofoil). Batasan tentang pesawat udara ditemukan dalam Annexes atau lampiran convensi Chicago 1944, Annexes 8, 9 dan 10, mengatakan bahwa pesawat udara ialah:

.... any machine which can derive support in the atmosphere from the reaction of the air other than from the reaction of the Earth's surface.

Dibandingkan dengan Konvensi Paris 1919, Sand, Pratt dan Lyon dalam bukunya An Historical Survey of The Law of Flight, bahwa kedaulatan Negara pada saat itu berorientasi pada aspek keamanan Negara sedangkan Konvensi Chicago 1944 pada aspek ekonomi bagi industri angkutan udara.(E.Suherman, 1983;168) Dalam tulisan ini ada beberapa pasal dalam Konvensi Chicago 1944 yang menjadi landasan analisis, yaitu:

Pasal 1 Konvensi Chicago 1944, mengakui adanya hak berdaulat di wilayah udara territorial suatu Negara yang berbunyi: The contracting States recognize that every State has complete 
and exclusive sovereignty over the airspace above its territory.

Pasal 3 sebagai implementasi pasal 1 tersebut di atas, menjelaskan: (b)Aircraft used in military, customs and police services shall be deemed to be state aircraft. (c)No state aircraft of a contracting State shall fly over the territ ory of another State or land thereon without authorization by special agreement or otherwise, and in accordance with the terms thereof. (d)The contracting State, undertake, when issuing regulations for their state aircraft, that they will have due regard for the safety of navigation of civil aircraft.

Annex Konvensi Chicago 1944 yang berhubungan dengan tulisan ini adalah Annex 2 tentang Rules of The Air. Beberapa yang dapat menjadi landasan yuridis yaitu bagian 2 ayat (1.1). bagian ini menegaskan bahwa ketentuan mengenai hokum udara harus tetap berlaku bagi setiap pesawat dimanapun mereka terbang dan tidak boleh ada konflik dengan ketentuan dari Negara lain. Disebutkan bahwa:

The rules of the air shall apply to aircraft bearing the nationality and registration marks of a contracting state, wherever they may be, to the extent that they do not conflict with the rules published by the State having jurisdiction over the territory overflown.
Undang-undang No. 1 Tahun 2009 tentang penerbangan merupakan landasan dari pelaksanaan penerbangan di wilayah Indonesia. Adapun pasalpasal yang berhubungan dengan tulisan ini adalah: Pasal 1 ayat (3), pesawat udara adalah setiap mesin atau alat angkat yang dapat terbang di atmosfir karena gaya angkat dari reaksi udara, tetapi bukan karena reaksi udara terhadap permukaan bumi yang digunakan untuk penerbangan. Sedangkan pesawat udara Negara adalah pesawat udara yang digunakan oleh TNI, kepolisisan RI, kepabeanan, dan instansi pemerintah lainnya untuk menjalankan fungsi dan kewenangan penegakan hokum serta tugas lainnya sesuai peraturan perundang-undangan (Pasal 1 ayat (7)). Pasal 5, Kedaulatan atas wilayah udara Indonesia dijelaskan dalam kalimat Negara Kesatuan Republik Indonesia berdaulat penuh dan eksklusif atas wilayah udara Republik Indonesia. Pasal 1 ayat (2) menjelaskan bahwa wilayah udara adalah wilayah kedaulatan udara di atas wilayah daratan dan perairan Indonesia. Pasal 6, bahwa penyelenggaraan kedaulatan Negara atas wilayah udara NKRI, pemerintah melaksanakan wewenang dann tanggungjawab pengaturan ruang udara untuk kepentingan penerbangan, perekonomian nasional, pertahanan dan keamanan Negara, social 
budaya, serta lingkungan udara. Pasal 8 ayat (1), bahwa pesawat udara yang melanggar kedaulatan NKRI sebagaimana dimaksud dalam Pasal 5 diperingatkan dan diperintahkan untuk meninggalkan wilayah tersebut oleh petugas pemandu lalu lintas penerbangan. Ketentuan lebih lanjut mengenai pelanggaran wilayah kedaulatan, penetapan kawasan terlarang, kawasan udara terbatas, pelaksanaan tindakan terhadap pesawat udara dan personel pesawat udara, serta tata cara dan prosedur pelaksanaan tindakan pemaksaan oleh pesawat udara Negara diatur dengan Peraturan pemerintah.

Undang-undang No. 43 Tahun 2008 tentang Wilayah Negara, memberikan landasan mengenai wilayah udara Indonesia dimana dapat ditegakkan peraturan perundang-undangan nasional. Pasal yang terkait adalah : Pasal 4, bahwa wilayah Negara meliputi wilayah darat, wilayah perairan, dasar laut, dan tanah di bawahnya serta ruang udara di atasnya, termasuk seluruh sumber kekayaan yang terkandung di dalamnya. Pasal 6 ayat (1) huruf (c), batas wilayah Negara di udara mengikuti batas kedaulatan negara di darat dan di laut, dan batasnya dengan angkasa luar ditetapkan berdasarkan perkembangan hukum internasional. Pasal 10 ayat (1) huruf (e), dalam pengelolaan wilayah negara dan kawasan perbatasan, Pemerintah berwenang memberikan izin kepada penerbangan internasional untuk melintasi wilayah udara teritorial pada jalur yang telah ditentukan dalam peraturan perundang-undangan;

Penjelasan Undang-undang No. 3 Tahun 2002 tentang Pertahanan Negara menegaskan bahwa undang-undnag ini merupakan dasar dari penyelenggaraan pertahanan Negara, sehingga segala bentuk atau tindakan yang berhubungan dengan penggunaan kekuatan harus mengacu pada pasal-pasal dalam undang-undang ini. Ada beberapa pasal yang menjadi dasar penggunaan kekuatan udara : Pasal 4, bahwa pertahanan Negara bertujuan untuk menjaga dan melindungi kedaulatan Negara, keutuhan wilayah Negara Kesatuan Republik Indonesia dan keselamatan segenap bangsa dari segala bentuk ancaman. Pasal 10 ayat (3), bahwa TNI bertugas melaksanakan kebijakan pertahanan Negara untuk melaksanakan Operasi Militer selain perang, dan salah satu pengertian operasi militer selain perang dalam penjelasan undang-undang ini adalah berupa pengamanan pelayaran atau penerbangan.

Beberapa pasal dari Undangundang no. 34 Tahun 2004 tentang TNI yang berkenaan dengan tulisan ini 
adalah:

Pasal 10 Angkatan Udara bertugas: (a) melaksanakan tugas TNI matra udara di bidang pertahanan, dan pada huruf (b), menegakkan hokum dan menjaga keamanan wilayah udara yurisdiksi nasional sesuai dengan ketentuan hokum nasional dan hokum internasional yang telah diratifikasi, maksudnya adalah segala usaha, pekerjaan dan kegiatan untuk menjamin terciptanya kondisi wilayah udara yang aman serta bebas dari ancaman kekerasan, ancaman navigasi, serta pelanggaran hokum di wilayah udara yurisdiksi nasional.

Pasal 20 ayat (2) menjelaskan penggunaan kekuatan TNI dalam rangka melaksanakan Operasi Militer selain perang, dilakukan untuk kepentingan pertahanan Negara dan/atau dalam rangka mendukung kepentingan nasional sesuai dengan peraturan perundang-undangan.

\section{Ketentuan Pesawat Udara Militer Menurut Hukum Udara Internasional}

Konferensi Paris 1910 telah membahas mengenai perbedaan antara pesawat udara sipil dan pesawat udara militer yang dikategorikan ke dalam pesawat udara negara, namun konferensi tersebut tidak berhasil mengesahkan konvensi internasional mengenai pengaturan penerbangan internasional sehingga tidak berhasil merumuskan perbedaan pesawat udara sipil dan pesawat udara Negara secara formil. Kemudian pada tahun 1919, telah berhasil mengesahkan Konvensi Internasional dengan judul Convention Relating to Regulation of Aerial Navigation, di Paris. (K.Martono, 1995:54) Dalam konvensi tersebut telah dirumuskan secara formal perbedaan antara pesawat udara sipil dan pesawat udara Negara.

Pasal 30 Konvensi Paris 1919 mengatakan bahwa pesawat udara Negara adalah pesawat udara militer, pesawat udara yang semata-mata untuk pelayanan public (public services) misalnya, pesawat udara militer, polisi dan bea cukai.(JC Cooper,1947:298) Pesawat udara sipil adalah pesawat selain pesawat udara militer, polisi dan bea cukai. Perbedaan kedua jenis pesawat udara ini berdasarkan hak dan kewajiban menurut hukum internasional yang diatur dalam Konvensi Paris 1919. Pengaturan lebih jelas terdapat dalam Pasal 32 yang berbunyi: "No military aircraft of a contracting states shall fly over the territory of another Contracting State nor land thereon without special authorization (permission)." Dijelaskan bahwa pesawat udara militer (Negara) tidak mempunyai hak untuk melakukan 
penerbangan di atas wilayah Negara anggota Konvensi Paris 1919. Sedangkan pesawat udara sipil diwaktu damai mempunyai hak untuk melakukan penerbangan lintas damai di atas wilayah Negara anggota lainnya, namun demikian wilayah Negara tersebut tidak berlaku untuk pesawat udara sipil yang melakukan dinas penerbangan internasional berjadwal maupun pesawat udara Negara. (K.Martono,1995;54)

Hal ini berarti pesawat udara militer tidak dapat dikenakan ketentuan hukum Negara lain yang berlaku seperti halnya terhadap pesawat udara sipil. Tambahan pula, awak pesawat udara militer memperoleh manfaat dari hak imunitas di dalam yurisdiksi kedaulatan Negara territorial lain hanya sepanjang tindakan dan sikapnya itu sesuai dengan apa yang menjadi misinya. Jika terjadi sengketa berkaitan dengan imigrasi, bea cukai, atau karantina, maka hak tuan rumah hanya terbatas pada meminta pesawat udara Negara tersebut untuk meninggalkan wilayahnya.

Ketentuan-ketentuan penerbangan internasional (termasuk perbedaan pesawat udara sipil dengan pesawat udara Negara) dalam Konvensi Paris 1919, diambil alih oleh Konvensi Havana 1928, yang kemudian kedua konvensi tersebut dicabut oleh Pasal 80 Konvensi Chicago 1944.
Ketentuan pembedaan pesawat udara sipil dengan pesawat udara Negara dalam Konvensi Chicago 1944 tercantum dalam Pasal 3 (c). Menurut pasal tersebut, pesawat udara sipil adalah selain daripada pesawat udara Negara, sedangkan yang dimaksud pesawat udara Negara adalah pesawat udara yang dipergunakan untuk militer, polisi dan bea cukai. Pesawat udara negara tidak mempunyai hak melakukan penerbangan di atas wilayah Negara anggota. Sebaliknya menurut Pasal 5 Konvensi Chicago 1944, pesawat udara selain pesawat udara militer, polisi dan bea cukai yang melakukan penerbangan internasional tidak berjadwal dapat melakukan di atas wilayah Negara anggota tanpa memperoleh ijin terlabih dahulu. Dalam praktek, ketentuan pasal 5 ini tidak dapat dilaksanakan karena setiap Negara berdasarkan paragraph 2 dapat mengenakan persyaratanpersyaratan tertentu yang berat dilaksanakan. (Haanappel PPC, 1978:13)

Menurut Priyatna, klasifikasi pesawat udara adalah sebagai berikut (Priyatna Abdurrasyid,2008;135) Pesawat udara (air craft): (1)Pesawat udara Negara (a)Pesawat udara militer (a1)Pesawat udara Angkatan Udara (a2)Pesawat udara Angkatan Laut (a3) Pesawat udara 
Angkatan Darat. (a4) Pesawat udara yang dimilterisasi (b)Pesawat udara Negara lainnya (b1)Pesawat udara yang digunakan untuk kepentingan Negara (b2)Pesawat udara polisi (b3) Pesawat udara bea-cukai (b4) Pesawat udara suatu jawatan pemerintah (2)Pesawat udara sipil (a)Pesawat udara komersial (b)Pesawat udara privat/ non komersial

Angkatan Laut Amerika Serikat mendefinisikan Pesawat udara militer dalam salah satu pedoman militernya sebagai: (Priyatna Abdurrasyid, 2008: 139)

All aircraft operated by commissioned units of armed forces of a nation bearing military markings of that nations, commanded by a member of the armed forces, and manned by a crew subject to regular armed forces discipline.

Sesuai dengan USAF tersebut, maka klasifikasi pesawat udara menurut Konvensi Chicago 1944 terdiri dari pesawat udara jenis berat dan jenis yang lebih ringan dari udara, tetapi tidak termasuk objek yang digolongkan sebagai peluru kendali, seperti roket. Pengendalian oleh awak bukan merupakan suatu ciri yang penting. Dengan demikian memungkinkan adanya pesawat yang tidak dikendalikan oleh pilot yang dalam hal ini masuk di dalam yurisdiksi pengaturan Konvensi Chicago 1944.

Konvensi Jenewa 1958 tentang
Convention on High Seas dan konvensi PBB tentang Hukum Laut mengatur juga mengenai pesawat udara Negara. Menurut konvensi jenewa 1958 istilah yang dipakai adalah pesawat udara militer (pesawat udara dinas pemerintah/government services) dan private aircraft. Private aircraft tidak mempunyai hak untuk menguasai atau menyita pesawat udara yang melakukan pelanggaran hukum, karena private aircraft tidak mempunyai kewenangan penegakan hukum. Kewenangan penegakan hukum tersebut hanya dimiliki oleh pesawat udara militer, pesawat udara dinas pemerintah sebagaimana diatur dalam Pasal 21 Konvensi jenewa 1958. Pasal tersebut secara lengkap berbunyi:

"A seizure on account of piracy may only be carried by warships or military aircraft or other ships or aircraft on government services authorized to that effect".

Pasal 107 Konvensi PBB tentang Hukum Laut mengatur pesawat udara yang mempunyai hak untuk menguasai atau menyita pesawat udara asing atau kapal asing yang dicurigai melakukan pelanggaran hukum. Pesawat udara yang berhak menyita hanyalah pesawat udara militer atau pesawat udara yang jelas ditandai dan dapat dikenali atau diketahui dinas pemerintah dan berwenang untuk maksud tersebut. Dengan 
demikian pesawat udara tersebut harus secara tegas dan jelas dipakai untuk dinas pemerintah. Disamping itu pesawat udara militer atau yang ditandai dengan jelas dinas pemerintah tersebut menurut pasal 111 (5) juga mempunyai hak pengejaran seketika terhadap kapal atau pesawat udara saing yang dicurigai melakukan pelanggaran. Disimpulkan bahwa walaupun tidak ada pasal yang secara khusus dalam Konvensi Jenewa 1958 dan Konvensi PBB tentang Hukum Laut, namun pembedaan pesawat udara sipil dan militer dapat dilihat dalam Pasal 21 juncto 23 (4) konvensi Jenewa 1958 dan Pasal 107 juncto Pasal 111 (5) Konvensi PBB tentang Hukum Laut.

\section{Ruang Lingkup Kedaulatan Negara}

Kedaulatan suatu Negara di ruang udara di wilayah teritorialnya bersifat utuh dan penuh (complete and exclusive sovereignty). Ketentuan ini merupakan salah satu tiang pokok hukum internasional yang mengatur ruang udara. Sebelumnya ketentuan tersebut telah hidup sebagai hukum kebiasaan internasional melalui praktek Negaranegara, terutama di Eropa.

Sifat kedaulatan yang utuh dan penuh dari Negara di ruang udara nasionalnya tersebut berbeda dengan sifat kedaulatan Negara di laut wilayahnya, karena sifatnya tersebut, maka di ruang udara nasional tidak dikenal hak lintas damai (innocent passage) pihak asing seperti di laut territorial suatu Negara. Ruang udara nasional suatu Negara sepenuhnya tertutup bagi pesawat asing, baik sipil maupun militer. Hanya dengan izin Negara kolong terlabih dahulu, baik melalui perjanjian bilateral maupun multilateral, maka ruang udara nasional dapat dilalui oleh pesawat udara asing.

\section{Kedaulatan Wilayah Udara Indonesia}

Kedaulatan Wilayah Negara berbentuk tiga dimensi. Masing-masing terjabarkan dalam wilayah darat, wilayah laut dan wilayah udara. Terdapat dua rujukan yang dapat dilihat untuk mengetahui dalam batas mana dan dimana Indonesia memiliki kedaulatan yang penuh dan eksklusif terhadap ruang udaranya, yaitu Undang-undang No. 1 Tahun 2009 tentang Penerbangan dan Undang-undang No. 43 Tahun 2008 tentang Wilayah Negara.

Negara Kesatuan Republik Indonesia berdaulat penuh dan eksklusif atas wilayah udara Republik Indonesia. Maknanya bahwa sebagai Negara berdaulat, Indonesia memiliki kedaulatan penuh dan utuh di wilayah udara Republik Indonesia, sesuai dengan ketentuan Konvensi Chicago 1944 dan Konvensi Hukum Laut Internasional 
1982 yang telah diratifikasi dengan UU Nomor 17 Tahun 1985 tentang Pengesahan UNCLOS. Ketentuan dalam pasal tersebut hanya menegaskan mengenai kewenangan dan tanggung jawab Negara Republik Indonesia untuk mengatur penggunaan wilayah udara yang merupakan bagian dari wilyah Indonesia.

Wilayah udara adalah wilayah kedaulatan udara di atas wilayah daratan dan perairan Indonesia. Ketentuan wilayah di atas dapat disimpulkan meliputi daratan berupa rangkaian pulau-pulau besar dan pulau-pulau kecil Indonesia; serta perairan Indonesia yang berarti menurut rezim hukum kepulauan (archipelagic state) adalah seluruh perairan pedalaman dan laut territorial Indonesia. Tidak berlaku Hak Lintas Damai (innocent passage) bagi pesawat udara asing (sipil maupun militer) dalam hal kedaulatan wilayah udara yang utuh.

Pembedaan pesawat militer di cantumkan dalam ketentuan umum mengenai Pesawat Udara Negara, yang dikelompokkan menjadi pesawat udara yang digunakan oleh Tentara Nasional Indonesia, Kepolisian Republik Indonesia, kepabeanan, dan instansi pemerintah lainnya. Pesawat udara Negara tersebut mengemban fungsi dan kewenangan untuk penegakan hukum serta tugas lainnya sesuai dengan peraturan perundang-undangan.

\section{Pelanggaran Kedaulatan Negara}

Pelanggaran wilayah udara (aerial intrusion) adalah suatu keadaan, di mana pesawat terbang suatu Negara sipil atau militer memasuki wilayah udara Negara lain tanpa izin sebelumnya dari Negara yang wilayahnya dimasuki itu. Katakata kunci di sini adalah tanpa izin sebelumnya dari Negara yang wilayahnya dimasuki.(Yasidi Hambali,1994:21) Kata-kata ini mengandung implikasi hukum, bahwa pada dasarnya wilayah udara suatu Negara adalah tertutup bagi pesawat-pesawat Negara lain. Penggunaan dan control atas wilayah udaranya hanya menjadi hak yang utuh dan penuh dari Negara kolongnya.

Diterimanya prinsip utuh dan penuh dalam Konvensi Paris 1919 dan Konvensi Chicago 1944, menunjukkan bahwa wilayah udara setiap Negara dinyatakan tertutup (the air is closed) dan bukannya bebas terbuka (the air is free). Konsep the air is closed dilandasi secara kuat oleh alasan pertimbangan keamanan Negara (security consideration). Hal tersebut telah didorong oleh adanya kesadaran Negara-negara akan sifat khusus dari potensi penggunaan pesawat udara sebagai alat utama system senjata teknologi. Terlihat bahwa ruang udara dapat dijadikan 
media serangan-serangan militer, suatu hal yang sangat rawan.

Demi pertimbangan keamanan Negara, penerapan hak control udara oleh suatu Negara dipergunakan dengan kadar keketatan yang berbeda antara penerapannya terhadap pesawat militer dan pesawat sipil Negara lain. Dalam Konvensi Paris 1919 maupun Konvensi Chicago 1944 hak control terhadap pesawat militer asing adalah ketat dan maksimal; ia tidak mengandung ketentuan-ketentuan perkecualian (Pasal 32 Konvensi Paris dan Pasal 3 (c) Konvensi Chicago 1944). Berbeda dengan hak control terhadap pesawat udara sipil asing yang mengandung perkecualian-perkecualian.

Dari uraian di atas jelaslah, bahwa bila diikuti prinsip-prinsip hukum sebagaimana dituangkan dalam konvensi-konvensi itu, maka dalam menangani kasus-kasus pelanggaran udara, Negara-negara harus menetapkan kadar penerapan control yang berbeda, antara perlakuan terhadap pesawat pelanggar (intruder) militer dan sipil. Tentunya terhadap pesawat intruder militer, penggunaan kekerasan senjata atas dasar pertimbangan keamanan Negara menjadi hal yang lazim dan sangat wajar dilakukan, berbeda dengan intruder pesawat sipil yang dengan cara apapun penggunaan kekerasan senjata tidak dapat dibenarkan. Hak control Negara yang keras dan maksimal atas wilayah udaranya seharusnya hanya ditujukan terhadap pesawat militer Negara lain, dimana faktor pertimbangan keamanan Negara menjadi alasan utamanya.

\section{Pelanggaran Pesawat Udara Militer Asing menurut Hukum Nasional}

Ruang lingkup berlakunya Undang-Undang No. 1 Tahun 2009 tentang Penerbangan salah satunya bagi semua pesawat udara asing yang melakukan kegiatan dari dan/atau ke wilayah Negara Kesatuan Republik Indonesia. Ketentuan ini menjelaskan bahwa semua penerbangan dengan menggunakan pesawat asing sipil maupun militer yang masuk wilayah Indonesia akan berlaku undang-undang penerbangan ini. Lebih luas lagi ketentuan tersebut guna memberikan perlindungan terhadap penerbangan sipil (dalam negeri atau asing) dari kemungkinan-kemungkinan digunakannya jalur-jalur penerbangan sipil oleh pesawat udara militer asing.

Secara umum pasal 8 menjelaskan bagi pesawat udara yang melanggar wilayah kedaulatan NKRI, terlebih dulu diperingatkan dan diperintahkan untuk meninggalkan wilayah tersebut oleh petugas pemandu 
lalu lintas penerbangan. Yang dimaksud dengan melanggar wilayah NKRI adalah memasuki wilayah NKRI.

Untuk pesawat udara Negara yang akan memasuki wilayah udara Negara lain harus dengan ijin khusus. Ijin khusus dapat dilihat dalam ketentuan Peraturan pemerintah No. 3 Tahun 2001 tentang Keamanan dan Keselamatan Penerbangan. Pasal 25 menyatakan bahwa penggunaan dan pengoperasian pesawat udara Negara diatur oleh Menteri yang bertanggung jawab di bidang masing-masing untuk pesawat militer oleh Menteri Pertahanan.

Ketentuan yang dimaksud sampai saat ini belum ada, hanya ada ketentuan tentang keharusan pesawat militer untuk mendapatkan izin Flight Clearance apabila melewati atau mendarat di wilayah Indonesia yaitu berdasarkan Keputusan Presiden No.4 Tahun 1972 tentang Perizinan Penerbangan Dalam dan Atas Wilayah Republik Indonesia. Dalam ketentuan tersebut dijelaskan dalam Pasal 2, sebagai berikut:

Izin penerbangan sebagai dimaksudkan dalam Pasall Keputusan Presiden ini dapat bersifat: (a)izin operasi (operating authorization) (b)flight approval (c)security clearance

$$
\text { Pasal } 3 \text { ayat (3) : Izin }
$$
penerbangan yang bersifat security clearance tersebut dalam Pasl 2 huruf(c) Keputusan Presiden ini, diberikan di dalam hal: (a)penerbangan tersebut diperkirakan dapat mempunyai pengaruh terhadap segi keamanan (b)penerbangan tersebut akan melalui daerah-daerah tertutup/terlarang.

UU No. 34 Tahun 2004 tentang TNI Pasal 10 menjelaskan tugas TNI AU sebagai bagian dari TNI. Salah satunya adalah menegakkan hukum dan menjaga keamanan di wilayah udara yurisdiksi nasional sesuai dengan ketentuan hukum nasional dan hukum internasional yang telah diratifikasi. Penegakan hukum adalah segala usaha, pekerjaan dan kegiatan untuk menjamin terciptanya kondisi wilayah udara yang aman serta bebas dari ancaman kekerasan, ancaman navigasi serta pelanggaran hukum di wilayah udara yurisdiksi nasional. Untuk melaksanakan tugas tersebut TNI AU melakukan suatu operasi pertahanan udara di wilayah kedaulatan dan/ mengurangi dampak suatu serangan udara.(Markas Besar TNIAU,2004:26)

Bagaimana dalam melaksanakan tugas tersebut hubungannya dengan pelanggaran wilayah udara. Dalam pelaksanaan Operasi Hanud tersebut dilaksanakan dengan tahap-tahap deteksi, identifikasi dan penindakan. Adapun proses penindakannya yang dilakukan oleh pesawat tempur sergap 
sebagi berikut: (Markas Besar TNIAU,2003:19); (1)Membayangbayangi (shadowing). Dilakukan terhadap setiap pesawat udara yang diperkirakan akan melanggar kedaulatan wilayah udara nasional. (2)Pengahalaun (intervention). Dilakukan terhadap setiap pesawat udara yang melanggar wilayah udara nasional atau jalur penerbangan yang telah ditentukan/ ketentuan ADIZ (Air Defence Indentification Zone) yang berlaku. (3)Pemaksaan mendarat (force down). Dilakukan terhadap setiap pesawat yang melanggar wilayah udara nasional dan dapat diperkirakan bermaksud untuk melakukan kegiatan-kegiatan yang tidak bersahabat. Tindakan ini hanya dilakukan bila dapat dipastikan pesawat udara tersebut tidak akan mengancam keselamatan objek-objek vital yang dilewatinya. Setelah pesawat mendarat dilanjutkan dengan penyidikan oleh pejabat penyidik TNI AU. (4)Penghancuran (destruction). Dilakukan oleh pesawat tempur sergap terhadap pesawat udara yang: (a)melanggar wilayah kedaulatan Negara dan tidak mengindahkan peringatan-peringatan yang diberikan; (b) secara nyata mengancam keselamatan objek-objek vital; (c)melakukan gerakan-gerakan yang membahayakan terhadap pesawat tempur sergap yang melaksanakan penyergapan. Ketentuan mengenai tindakan menghadapi kondisi demikian diatur tersendiri dalam ROE (Rule of Engagement).

\section{PENUTUP}

Dari pemaparan di atas maka dapat disimpulkan (1)Pada prinsipnya pesawat udara militer (Negara) tidak mempunyai hak untuk melakukan penerbangan di atas wilayah Negara anggota Konvensi, dan apabila tidak memperoleh izin terlebih dahulu dari Negara kolong maka dapat dilakukan upaya-upaya penghalangan, pengusiran hingga penggunaan kekerasan. (2)Beberapa tindakan yang dapat dilakukan terhadap pelanggaran kedaulatan yang dilakukan oleh pesawat udara militer asing di wilayah udara nasional: (a)Membayang-bayangi (shadowing) (b) Penghalaun (intervention) (c)Pemaksaan mendarat (force down) (d)Penghancuran (destruction). Dilakukan oleh pesawat tempur sergap terhadap pesawat udara yang melanggar wilayah kedaulatan Negara dan tidak mengindahkan peringatan-peringatan yang diberikan, mengancam keselamatan objek-objek vital, melakukan gerakan-gerakan yang membahayakan terhadap pesawat tempur sergap yang melaksanakan penyergapan. 


\section{DAFTAR PUSTAKA}

Buku

E. Suherman, (1983). Hukum Udara Indonesia dan Internasional, Alumni, Bandung,

Haanappel P.P.C, (1978). Rate-making in International Air Transport, Kluwer, The Netherlands

Hans Kelsen, (1961). General Theory Of Law and State, Russel, New York, diterjemahkan dalam bahasa inggris oleh anders Wedberg

JC. Cooper, (1947). The Right to Fly

J.L. Briefly, (1963). The Law of Nations, Oxford University Press, Oxford, new York,

K. Martono, (1995). Hukum Udara, Angkutan Udara dan Hukum angkasa, Hukum Laut Internasional, Mandar Maju, Bandung

Markas Besar TNI AU, (2004). Doktrin TNI AU Swa Bhuwana Paksa, Jakarta

Markas Besar TNI , (2003).Buku Petunjuk Pelaksanaan OPSGAB TNI Tentang Operasi Hanud Nasional, Jakarta

Priyatna Abdurrasyid, (1972). Kedaulatan Negara di Ruang Udara, Air \& Space Law Centre, Jakarta

, (2008). Beberapa Bentuk Hukum Sebagai Pengantar Menuju Indonesia Emas 2020, Fikahati Aneska kerjasama dengan
BANI, Jakarta

Soerjono Soekanto, (1986). Pengantar Penelitian Hukum, UI Press, Jakarta

Wenceslas J. Wagner, (1970). International air Transportation As Affected by State Sovereignty, Bruylant Bruxelles

Yasidi Hambali, (1994). Hukum dan Politik Kedirgantaraan, Pradnya Paramita, Jakarta,

\section{Konvensi/ Perjanjian Internasional}

Convention Relating To The Regulation Of Aerial Navigation 1919 (Konvensi Paris 1919)

Convention On International Civil Aviation 1944 (Konvensi Chicago 1944)

Annex 2 Konvensi Chicago 1944 tentang Rule of Air

\section{Peraturan Perundang-undangan}

Undang-undang Nomor 1 Tahun 2009 tentang Penerbangan

Undang-undang No. 43 Tahun 2008 tentang Wilayah Negara

Undang-undang No. 3 Tahun 2002 tentang Pertahanan Negara

Undang-undang no. 34 tahun 2004 tentang TNI

\section{Website}

http://makaarim.wordpress.com/2008/1 1/28/strategi-pengelolaan-danpertahanan-wilayah-perbatasanudara-republik-indonesial, diakses tanggal 2 Juni 2009

http://www.tvone.co.id/mobile/read.php $? i d=15225$, diakses tanggal 5 Juni 2009 